\title{
Quality of soybean seeds treated with fungicides and insecticides before and after storage ${ }^{1}$
}

\author{
Thaís Francielle Ferreira ${ }^{2 *}$, João Almir Oliveira², Rafaela Aparecida de Carvalho², \\ Laís Sousa Resende², Cassiano Gabriel Moreira Lopes², Valquíria de Fátima Ferreira²
}

\begin{abstract}
The timing of seed treatment application is important to keep soybean seeds quality. Therefore, the aim of this study was verify the effect of fungicides and insecticides treatment in soybean seeds quality before and after storage. Seeds of NS 7494, NS 8693 and NS 7338 IPRO were utilized and analyses separately, through a factorial scheme $3 \times 6$, with three application moments: treated and assessed; treated, stored and assessed; stored, treated and assessed; and six combination

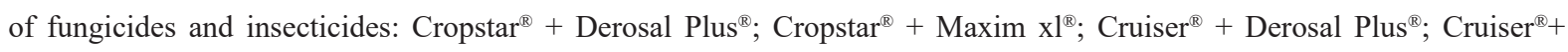

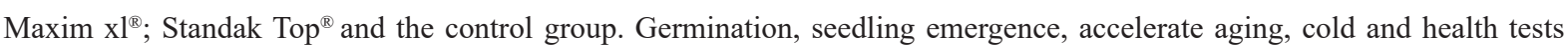
were performed. It was determined that the combination with Cruiser ${ }^{\circledR}$ doesn't affect the physiological quality of soybean seeds treated and assessed, and treated after two month of storage. Cropstar ${ }^{\circledR}+$ Derosal plus ${ }^{\circledR}$ keeps physiological quality of soybean seeds stored and treated for two months, while Standak top ${ }^{\circledR}$ has negative effect. The combination with Cropstar ${ }^{\circledR}$ damages the physiological quality of soybean seeds treat after two months of storage. The fungicide Derosal plus ${ }^{\circledR}$ improves the health quality of soybean seeds regardless treatment moment.
\end{abstract}

Index terms: Glycine $\max$ L., seed treatment, health.

\section{Qualidade de sementes de soja tratadas com inseticidas e fungicidas antes e após o armazenamento}

\begin{abstract}
RESUMO - O momento de aplicação do tratamento de sementes é importante para a manutenção da qualidade de sementes de soja. Assim, objetivou-se verificar o efeito do tratamento fungicida e inseticida na qualidade de sementes de soja antes e após o armazenamento. Utilizou-se sementes das cultivares NS 7494, NS 8693 e NS 7338 IPRO, que foram analisadas separadamente, em esquema fatorial de $3 \times 6$. Três momentos de aplicação em que as sementes foram: tratadas e avaliadas; tratadas, armazenadas e avaliadas; armazenadas, tratadas e avaliadas; e seis combinações de inseticidas e fungicidas: Cropstar ${ }^{\mathbb{B}}$

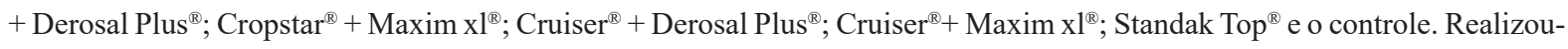
se testes de germinação, emergência, envelhecimento acelerado, frio e sanidade. Concluiu-se que as misturas com Cruiser ${ }^{\mathbb{R}}$ não afetam a qualidade fisiológica de sementes de soja tratadas e avaliadas, e tratadas após dois meses de armazenamento. Cropstar $^{\circledR}+$ Derosal Plus $^{\circledR}$ mantém a qualidade fisiológica de sementes de soja armazenadas tratadas por dois meses, enquanto que o Standak Top ${ }^{\circledR}$ tem efeito negativo. As misturas com Cropstar ${ }^{\circledR}$ prejudicam a qualidade fisiológica de sementes de soja tratadas após dois meses de armazenamento. O fungicida Derosal Plus ${ }^{\circledR}$ melhora a qualidade sanitária de sementes de soja independentemente do momento de tratamento.
\end{abstract}

Termos para indexação: Glycine $\max$ L., tratamento de sementes, sanidade.

\section{Introduction}

Seed treatment is a technology that, when associated with plant genetic improvement and biotechnology, allows high productivity of soybean culture and producer satisfaction in meeting the demands of the market. This market, in its turn, is supported by the use of quality seeds, which, as a vehicle of technology and innovations, is responsible for stimulate it and make it competitive, since the advance of Brazilian agribusiness is characterized largely by the development of the system of seed production.

This aspect brings in response the search for the conquest

${ }^{1}$ Submitted on $03 / 29 / 2016$. Accepted for publication on 10/10/2016.

${ }^{2}$ Departamento de Agricultura, Universidade Federal de Lavras, Caixa Postal 3037, 37200-000 - Lavras, MG, Brasil.

*Corresponding author < franthata@yahoo.com.br> 
of new markets by large companies investing in values and very impactful strategies as the launching of large-scale agricultural inputs to the commercialization and deployment of innovative technologies as the industrial seed treatment.

Today, industrial seed treatment guarantees the maximum efficiency of the products used and the quality of the seeds, no risk for operators, while in the past decades, most of the seed treatment was carried out on the properties so that both the quality of the seeds as the health of the operator were committed (Zambom, 2013).

However, after the resolution of the operational aspects of the treatment of seeds, certain limitations are of concern, such as the possible effects of the active ingredients in the quality of the seeds during storage and in the field (Brzezinski et al., 2015).

In this way, the need arises for studies that assess the effect of seed treatment products used commercially and launched recently in the market and the right time of application on the quality of soybean seeds. Considering that, according to the MAPA (2016), until the present time, there are twenty fungicides and twenty-three insecticides intended for the chemical treatment of seeds.

Thus, the objective of this study was to check the effect of the fungicide and insecticide treatment on the quality of soybean seeds before and after storage.

\section{Material and Methods}

The experiments were conducted on University Federal of Lavras, in Lavras, MG, in the Departments of Agriculture and Plant Pathology, with physiological analyses carried out at the Central Laboratory for Seed Testing and phyto-sanitary analysis, at Laboratory of Seed Pathology.

The seed used for the experiment were provided by company Nidera Seeds, with the cultivars NS 7494, NS 8693 and NS 7338 IPRO.

A completely randomized factorial $3 \times 6$ was used, with three times of application of chemical treatment and six mixtures of fungicides and insecticides, with four replications The cultivars data were analyzed separately.

Seeds from each cultivar were subjected to three treatments which differed from each other by the time they received the chemical treatment: 1) treated and assessed (the seeds were assessed immediately after the chemical treatment); 2) treated, stored and assessed (the seeds were stored with chemical treatment for two months and then assessed); 3) stored, treated and assessed (the seeds were stored without chemical treatment for two months, and then were treated and immediately assessed).

The products used for the chemical treatment of the seeds were the insecticides Cropstar $^{\circledR}$, which active ingredients are imidacloprid and tiocarbe; and Cruiser $^{\circledR}$, with active ingredient thiamethoxam; the fungicide Derosal Plus ${ }^{\circledR}$, which has carbendazim and thiram in its composition; and Maxim $\mathrm{xl}^{\circledR}$, chemical based on fludioxonil and metalaxyl-M; Standak Top $^{\circledR}$, that is a mixture containing the insecticide fipronil and ready the fungicides pyraclostrobin and thiophanate methyl.

For the treatment of seeds, the products have been combined as follows with the respective dosing: Cropstar $^{\circledR}(5$ $\left.\mathrm{mL} \cdot \mathrm{Kg}^{-1}\right)+$ Derosal Plus $^{\circledR}\left(2 \mathrm{~mL} \cdot \mathrm{Kg}^{-1}\right), \operatorname{Cropstar}^{\circledR}\left(5 \mathrm{~mL} \cdot \mathrm{Kg}^{-1}\right)$ $+\operatorname{Maxim~xl}^{\circledR}\left(1 \mathrm{~mL} \cdot \mathrm{Kg}^{-1}\right), \mathrm{Cruiser}^{\circledR}\left(2.5 \mathrm{~mL} \cdot \mathrm{Kg}^{-1}\right)+$ Derosal $\operatorname{Plus}^{\circledR}\left(2 \mathrm{~mL} \cdot \mathrm{Kg}^{-1}\right)$, Cruiser $^{\circledR}\left(2.5 \mathrm{~mL} \cdot \mathrm{Kg}^{-1}\right)+$ Maxim xl $^{\circledR}(1$ $\left.\mathrm{mL} . \mathrm{Kg}^{-1}\right)$, Standak Top ${ }^{\circledR}\left(2 \mathrm{~mL} . \mathrm{Kg}^{-1}\right)$ and the Control group, which received only addition of water.

The amount of the solution of the mixture to the treatments was determined according to the dose recommended for each commercial product and amount of water until the maximum volume of $10 \mathrm{~mL} \cdot \mathrm{Kg}^{-1}$ of seeds.

The amount of $500 \mathrm{~g}$ of seeds for each of the mixtures was used. For the application of the products in the seeds plastic bags of $2 \mathrm{Kg}$ capacity were used. The products were previously mixed in a Petri dish (+ fungicide insecticide + water) and placed in plastic bags, followed by the seeds. The set was shaken until it obtained a homogeneous mixture of seeds. After treatment, the seeds were laid out in the shade, at a temperature of approximately $25{ }^{\circ} \mathrm{C}$ for 20 minutes, for drying of the product on the surface of the seed.

After drying, the seeds were placed in multiwall paper packaging and held for two months in storage, in uncontrolled conditions, average temperature of $20.4{ }^{\circ} \mathrm{C}$ and average of relative humidity in $65.5 \%$ (Dantas et al., 2007).

For the evaluation of the seed quality germination, emergence, accelerated aging, cold test and seed health tests were carried out.

In the germination test four replications of 50 seeds per plot were used, sown on two sheets of towel paper and covered with a sheet, moistened with distilled water in quantity equivalent to 2.5 times the weight of the dry paper. The rolls were kept in a germinator at $25^{\circ} \mathrm{C}$, the evaluations were conducted at eight days after sowing and the results expressed as percentage of normal seedlings (Brasil, 2009).

In the accelerated aging test, 250 seed samples were placed on metallic screens in plastic boxes adapted containing $40 \mathrm{~mL}$ of distilled water. These boxes were kept in an incubator, at $42^{\circ} \mathrm{C}$ for 48 hours, on incubator type BOD (Marcos-Filho, 1999). Then we proceeded to the germination test with four subsamples of 50 seeds. The evaluation took place five days after sowing. The results were expressed as percentage of mean normal seedlings for each treatment (Brasil, 2009). 
In the emergence test, the sowing was carried out in plastic trays containing substrate, soil + sand in the ratio $2: 1$. Four replications of 50 seeds were sown. After sowing, the trays were kept in plant growth chamber at a temperature of $25^{\circ} \mathrm{C}$, in alternating light and dark regime ( 12 hours). The number of emerged seedlings was determined 14 days after sowing. The results were expressed as percentage of seedlings.

In the cold test, the same procedures of the emergence test were performed, however, after sowing, the trays were placed in cold chamber at $10{ }^{\circ} \mathrm{C}$ for seven days and then taken to germinator at $25^{\circ} \mathrm{C}$ for seven more days. Then the number of emerged seedlings was determined. The results were expressed as percentage of seedlings.

For the health test, we used the method of incubation in filter paper (Neergaard, 1979), with eight subsamples of 25 seeds. The seeds were distributed in Petri dishes of 15 $\mathrm{cm}$ in diameter containing three previously sterilized filter paper sheets and moistened with water, and $2.4 \mathrm{D}$ sterile agar. The dishes were kept in incubation at $20{ }^{\circ} \mathrm{C}$ and photoperiod of 12 hours, where they remained for seven days, and then assessed for the presence of pathogens (Brasil, 2009). For the identification of pathogens present in the seeds, a stereoscopic magnifying glass and an optical microscope were used. The incidence was assessed in percentage of fungi found.

Statistical analysis was performed using the statistical software Sisvar $^{\circledR}$ (Ferreira, 2011). In the analysis, when significant effect of the treatments was verified, to test the significance of differences between the averages of the treatments, the medium test Scott-Knott was used, with $5 \%$ probability. Fungal incidence values were previously transformed into $(\sqrt{ } \mathrm{x}+1)$.

\section{Results and Discussion}

The interaction between the factors times of application and mixtures of insecticides and fungicides was significant for the germination, accelerated aging, cold and emergency tests, to the level of $1 \%$ and $5 \%$ of probability (Table $1 \mathrm{~A}$ ).

The results of the test of germination, the seeds from cultivars NS 7494 and NS 7338 IPRO treated before testing obtained generally better performance when compared to the seeds stored with or without treatment, which proves that the pre-planting treatment favours the establishment of plants in the field and grain production in relation to the anticipated treatment (Table 1) (Brzezinski et al., 2015).

Table 1. Germination (\%) of seeds from three soybean cultivars treated with different products at different times of application.

\begin{tabular}{|c|c|c|c|c|}
\hline \multirow{2}{*}{ Cultivars } & \multicolumn{4}{|c|}{ Application Time } \\
\hline & Products & Treat & Treat + Stored & Stored + Treat \\
\hline \multirow{6}{*}{$\begin{array}{c}\text { NS } 7494 \\
(\mathrm{VC}=2.26 \%)\end{array}$} & Cropstar $^{\circledR}+$ Derosal Plus ${ }^{\circledR}$ & $87 \mathrm{aC}$ & $83 \mathrm{bC}$ & $70 \mathrm{cD}$ \\
\hline & Cropstar $^{\circledR}+$ Maxim xl $^{\circledR}$ & $89 \mathrm{aC}$ & $92 \mathrm{aB}$ & $71 \mathrm{bD}$ \\
\hline & Cruiser $^{\mathbb{B}}+$ Derosal Plus $^{\circledR}$ & $97 \mathrm{aA}$ & $91 \mathrm{bB}$ & $98 \mathrm{aA}$ \\
\hline & Cruiser $^{\mathbb{R}}+$ Maxim xl $^{\mathbb{R}}$ & $94 \mathrm{aB}$ & $85 \mathrm{bC}$ & $81 \mathrm{cC}$ \\
\hline & Standak Top $^{\circledR}$ & $93 \mathrm{bB}$ & $97 \mathrm{aA}$ & $80 \mathrm{cC}$ \\
\hline & Control & $95 \mathrm{aB}$ & $85 \mathrm{cC}$ & $91 \mathrm{bB}$ \\
\hline \multirow{6}{*}{$\begin{array}{c}\text { NS } 8693 \\
(\mathrm{VC}=3.50 \%)\end{array}$} & Cropstar $^{\mathbb{R}}+$ Derosal Plus $^{\mathbb{R}}$ & $90 \mathrm{aB}$ & $92 \mathrm{aA}$ & $57 \mathrm{bC}$ \\
\hline & Cropstar $^{\circledR}+$ Maxim xl $^{\circledR}$ & $91 \mathrm{aB}$ & $91 \mathrm{aA}$ & $56 \mathrm{bC}$ \\
\hline & Cruiser $^{\circledR}+$ Derosal Plus ${ }^{\circledR}$ & $95 \mathrm{aA}$ & $87 \mathrm{bB}$ & $82 \mathrm{cA}$ \\
\hline & Cruiser $^{\circledR}+$ Maxim xl $^{\circledR}$ & $81 \mathrm{bD}$ & $92 \mathrm{aA}$ & $79 \mathrm{bA}$ \\
\hline & Standak Top ${ }^{\circledR}$ & $87 \mathrm{aC}$ & $85 \mathrm{aB}$ & $73 \mathrm{bB}$ \\
\hline & Control & $95 \mathrm{aA}$ & $94 \mathrm{aA}$ & $70 \mathrm{bB}$ \\
\hline \multirow{6}{*}{$\begin{array}{c}\text { NS } 7338 \text { IPRO } \\
(\mathrm{VC}=3.33 \%)\end{array}$} & Cropstar $^{\mathbb{R}}+$ Derosal Plus ${ }^{\mathbb{R}}$ & $87 \mathrm{aB}$ & $74 \mathrm{bD}$ & $64 \mathrm{cD}$ \\
\hline & Cropstar $^{\circledR}+$ Maxim xl $^{\circledR}$ & $91 \mathrm{aB}$ & $88 \mathrm{aB}$ & $73 \mathrm{bC}$ \\
\hline & Cruiser $^{\circledR}+$ Derosal Plus $^{\circledR}$ & $96 \mathrm{aA}$ & $85 \mathrm{bC}$ & $84 \mathrm{bB}$ \\
\hline & Cruiser $^{\circledR}+$ Maxim xl $^{\circledR}$ & $93 \mathrm{aA}$ & $90 \mathrm{aB}$ & $90 \mathrm{aA}$ \\
\hline & Standak Top ${ }^{\circledR}$ & $92 \mathrm{aA}$ & $85 \mathrm{bC}$ & $86 \mathrm{bB}$ \\
\hline & Control & $90 \mathrm{bB}$ & $98 \mathrm{aA}$ & $86 \mathrm{bB}$ \\
\hline
\end{tabular}

The averages followed by the same low case letter in the lines and capital letter in the column do not differ between each other by the Scott-Knott test, at $5 \%$ probability.

The lower averages of germinated seeds, cultivar NS 7494, were obtained when the seed treatment was carried out after two months of storage in conventional warehouse conditions, with the exception of treatment Cruiser $^{\circledR}+$ Derosal Plus $^{\circledR}$, since 
the mixture provided an increase in germination of these seeds when comparing to the control, both in post treatment storage and pre-treatment tests. Regarding the seeds treated and stored for two months, the Standak Top ${ }^{\circledR}$ product was the one which provided the largest percentage of normal seedlings, contrary to the results found by Souza et al. (2015), in which even without storing the treated seeds, concluded that the Standak Top ${ }^{\circledR}$ was unfavorable to the development of seedlings.

When treatment with Cruiser ${ }^{\circledR}+$ Derosal Plus $^{\circledR}$ was held in seeds of cultivar NS 8693 before the quality tests, the percentage of germinated seeds remained the same when copared to the control, unlike other treatment with products that contributed to the reduction of seed germination. The seeds that were stored with this same treatment obtained less percentage of germination, unlike the seeds who received the treatment after two months of storage, which obtained an increase in germination. This shows that the product Cruiser $^{\circledR}+$ Derosal Plus $^{\circledR}$ is detrimental to seed during storage. However, when the quality tests are done before, regardless of whether the seeds were stored or not, the treatment helps to enhance germination. Dan et al. (2013) when studying the physiological potential of soybean seeds treated with thiametoxan, a.i. of Cruiser ${ }^{\circledR}$, and submitted to storage, observed that there is a reduction in germination of seeds treated during the storage, however, when the treatment is performed pre sowing, the product acts like bio-activator and increments germination, emergence and agronomic characteristics of seedlings, which corroborates with the results described.

As well as mixing Cruiser ${ }^{\circledR}+$ Derosal Plus $^{\circledR}$, the Standak $^{\circledR}$ Top product was also harmful to seed germination of NS 8693 cultivar when these were stored. Cunha et al. (2015), with the objective of evaluating the phyto-toxic effect of seed treatment products on the physiological quality of soybean seeds, have observed a lower performance of seeds treated with Standak Top $^{\circledR}$ in the accelerated aging test, which allows to evaluate the potential for seed storage. This lower performance in accelerated aging test is related with the lowest germination of stored seeds treated with Standak Top ${ }^{\circledR}$.

The combinations containing the insecticide Cruiser $^{\mathbb{R}}$ in its composition have contributed to a better germination of the cultivar NS 8693, while other products have reduced germination when the treatment was held after two months of storage.

For the cultivar NS 7338 IPRO, the timing of the treatment of the seeds did not influence seed germination

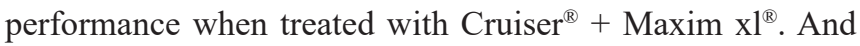

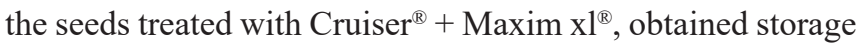
after a larger percentage of germination when compared to other products treatment, which demonstrates that this association is compatible since it reaches the expected result with treatment: maintaining or increasing the quality of seeds (Follmann et al., 2014).

Seed germination of cultivar NS 7338 IPRO treated before the quality tests was higher when the products used were Standak Top ${ }^{\circledR}$ and containing the insecticide Cruiser ${ }^{\circledR}$ combined with the fungicide when compared to the control, due to the low deleterious effect of these products the seeds (Zilli et al., 2010; Dan et al., 2013).

Regardless of the product used for the treatment and of cultivars, seed germination was reduced in the treated and stored and the smallest seedlings were obtained when the seeds quality after storage were assessed. This reduction in germination of seeds is due to many circumstances such as the environmental conditions during the production of seeds, insect attack, lipid and water content in seeds, presence of mechanical damage arising from transport and processing, storage conditions, and especially, in the case of seed with high quality, of the chemicals used in seed treatment (Sales et al., 2011). In this study, when the seeds were stored there was phytotoxic effect treated by the contact time of the products with the seeds. And when the treatment was done after there was storage phytotoxicity by the entry of products within seeds due to the damage caused by storage fungi (Table 5).

In the same way that occurred in the first count of germination, it is observed that when the treatment was done after two months of storage, there was lower percentage of germination, when comparing to other moments of seed treatment, especially when using the Cropstar ${ }^{\circledR}$ product in combination with the fungicide, regardless of the plant variety which received the treatment.

In the accelerated aging test, seed treatments containing in its formula the fungicide Derosal Plus ${ }^{\circledR}$ contributed to a greater percentage of normal seedlings for 'NS 7494', regardless of when that treatment was held (Table 2). This behavior is evidenced by the health check of seeds in which the seed treatment formulations containing the Derosal Plus ${ }^{\circledR}$ were able to control the fungus in almost its entirety for any time of treatment (Table 5).

The seeds of the cultivar NS 8693 treated with Cropstar ${ }^{\circledR}$ + Derosal Plus ${ }^{\circledR}$ obtained larger numbers of normal seedlings after accelerated aging seed regardless of how they were treated, which goes against the results obtained by Cunha et al. (2015) who observed the maintenance of quality of seeds treated with Cropstar ${ }^{\circledR}$ after accelerated aging of seeds. For this same cultivar, chemical treatment of the seed has contributed to an increase in the number of normal seedlings after accelerated aging of seeds that received treatment after storage. 
Table 2. Accelerated ageing (\%) of seeds from three soybean cultivars treated with different products at different times of application.

\begin{tabular}{|c|c|c|c|c|}
\hline \multirow{2}{*}{ Cultivars } & & \multicolumn{3}{|c|}{ Application Time } \\
\hline & Products & Treat & Treat + Stored & Stored + Treat \\
\hline \multirow{6}{*}{$\begin{array}{c}\text { NS } 7494 \\
(\mathrm{VC}=2.87 \%)\end{array}$} & Cropstar $\left.^{(}\right)+$Derosal Plus ${ }^{\circledR}$ & $42 \mathrm{cA}$ & $85 \mathrm{aA}$ & $78 \mathrm{bA}$ \\
\hline & Cropstar $^{\circledR}+$ Maxim xl $^{\circledR}$ & $26 \mathrm{cB}$ & $76 \mathrm{aD}$ & $71 \mathrm{bB}$ \\
\hline & Cruiser $^{\circledR}+$ Derosal Plus ${ }^{\circledR}$ & $42 \mathrm{cA}$ & $86 \mathrm{aA}$ & $80 \mathrm{bA}$ \\
\hline & Cruiser $^{(\mathbb{B}}+$ Maxim xl $^{\circledR}$ & $24 \mathrm{cB}$ & $76 \mathrm{aD}$ & $63 \mathrm{bC}$ \\
\hline & Standak Top ${ }^{\circledR}$ & $21 \mathrm{cC}$ & $82 \mathrm{aB}$ & $70 \mathrm{bB}$ \\
\hline & Control & $21 \mathrm{cC}$ & $80 \mathrm{aC}$ & $71 \mathrm{bB}$ \\
\hline \multirow{6}{*}{$\begin{array}{c}\mathrm{NS} 8693 \\
(\mathrm{VC}=3.72 \%)\end{array}$} & Cropstar $^{\circledR}+$ Derosal Plus $^{\circledR}$ & $22 \mathrm{cA}$ & $82 \mathrm{aA}$ & $63 \mathrm{bA}$ \\
\hline & Cropstar $^{\circledR}+$ Maxim xl $^{\circledR}$ & $17 \mathrm{cB}$ & $80 \mathrm{aB}$ & $63 \mathrm{bA}$ \\
\hline & Cruiser $^{\circledR}+$ Derosal Plus $^{\circledR}$ & $22 \mathrm{cA}$ & $70 \mathrm{aC}$ & $57 \mathrm{bB}$ \\
\hline & Cruiser $^{(\mathbb{B}}+$ Maxim xl $^{\circledR}$ & $3 \mathrm{cD}$ & $65 \mathrm{aD}$ & $52 \mathrm{bC}$ \\
\hline & Standak Top ${ }^{\circledR}$ & $14 \mathrm{cC}$ & $62 \mathrm{aE}$ & $53 \mathrm{bC}$ \\
\hline & Control & $6 \mathrm{cD}$ & $84 \mathrm{aA}$ & $48 \mathrm{bD}$ \\
\hline \multirow{6}{*}{$\begin{array}{c}\text { NS } 7338 \text { IPRO } \\
(\mathrm{VC}=4.36 \%)\end{array}$} & Cropstar $\left.^{(}\right)+$Derosal Plus ${ }^{\circledR}$ & $69 \mathrm{bA}$ & $73 \mathrm{aB}$ & $59 \mathrm{cC}$ \\
\hline & Cropstar $^{\circledR}+$ Maxim xl $^{\circledR}$ & $48 \mathrm{cB}$ & $72 \mathrm{aB}$ & $62 \mathrm{bC}$ \\
\hline & Cruiser $^{\circledR}+$ Derosal Plus ${ }^{\circledR}$ & $34 \mathrm{cD}$ & $73 \mathrm{aB}$ & $69 \mathrm{bB}$ \\
\hline & Cruiser $^{\circledR}+$ Maxim xl $^{\mathbb{R}}$ & $43 \mathrm{cC}$ & $63 \mathrm{aC}$ & $54 \mathrm{bD}$ \\
\hline & Standak Top ${ }^{\circledR}$ & $11 \mathrm{bE}$ & $83 \mathrm{aA}$ & $86 \mathrm{aA}$ \\
\hline & Control & $7 \mathrm{cF}$ & $25 \mathrm{bD}$ & $61 \mathrm{aC}$ \\
\hline
\end{tabular}

The averages followed by the same low case letter in the lines and capital letter in the column do not differ between each other by the Scott-Knott test, at $5 \%$ probability.

For NS 7338 IPRO cultivar, mixing products the Cropstar ${ }^{\mathbb{R}}+$ Derosal Plus ${ }^{\circledR}$ contributed to an increase in the number of normal seedlings in treated seeds before the quality tests, which shows that these products do not have phytotoxic effect on the seeds over a period of two months in contact with the seeds and offer high protection as the results found by Conceição et al. (2014). As well as on a study by Cunha et al. (2015), the Standak Top ${ }^{\circledR}$ product contributed to a poor performance in the accelerated aging when comparing seeds treated before the tests against the seeds stored and treated seeds after storage.

In general, regardless of the cultivars, there was low germination after accelerated aging of seeds which served as control. This is due to the presence of storage and field fungi (Table 5). The seeds that have received treatment without storing had the smallest average germination obtained, as well as of the product concentration, time of contact with the seed treatment was lower and this implies a smaller action of active ingredients on the fungi that came directly from the field. However, when the seeds were stored, there has been a natural reduction of fungi that came from the field, as is noted in the control and in the seeds who received treatment after the storage (Table 5). In this way, the seeds stored handled in addition to being protected against fungi had storage fungi of field eliminated by the action of chemical treatment. The seed treatment with fungicides, in addition to controlling important pathogens transmitted via seeds, is important to ensure adequate populations of plants when the soil and climate conditions are unfavorable (Zorato and Henning, 2001).

The application of products held prior to storage of seed has contributed to a better expression of quality in the accelerated aging test. In the accelerated aging test, products tend to focus, as there are high relative humidity and high temperature, which can cause damage to seed due to penetration of products in the membrane. Thus, seed germination is reduced by the fact that the toxic potential of treatment products is intensified in stress conditions (Pereira et al., 2007).

The chemical treatment of seeds has contributed to increase the virgor expression by the stress caused by the accelerated aging test. Regarding field levels, this result was found by Brzezinski et al. (2015) who observed in their study that the beneficial effect of treatment products to control pathogens and insects was higher when coincided with adverse conditions of temperature and rainfall distribution during the establishment of culture.

In the cold test, to cultivar seeds NS 7494 treated before the quality tests, there was improved performance in vigor when the treatment was with Cropstar $^{\mathbb{Q}}+$ Plus Derosal $^{\circledR}$ and it remained with the Standak Top ${ }^{\circledR}$ treatment (Table 3). The same result was found by Dan et al. (2010) and Castro et al. (2008) that, when testing the Cropstar ${ }^{\circledR}$ insecticide on soybean seeds, observed higher vigor from seeds treated with these insecticide even after 45 days of storage. The other products contributed 
Table 3. Cold test (\%) of seeds from three soybean cultivars treated with different products at different times of application.

\begin{tabular}{|c|c|c|c|c|}
\hline \multirow{2}{*}{ Cultivars } & \multicolumn{4}{|c|}{ Application Time } \\
\hline & Products & Treat & Treat + Stored & Stored + Treat \\
\hline \multirow{6}{*}{$\begin{array}{c}\text { NS } 7494 \\
(\mathrm{VC}=1.76 \%)\end{array}$} & Cropstar $^{(B)}+$ Derosal Plus ${ }^{(B)}$ & $77 \mathrm{cA}$ & $93 \mathrm{aB}$ & $85 \mathrm{bB}$ \\
\hline & Cropstar $^{\circledR}+$ Maxim xl $^{\circledR}$ & $60 \mathrm{cD}$ & $98 \mathrm{aA}$ & $89 \mathrm{bA}$ \\
\hline & Cruiser $^{\circledR}+$ Derosal Plus ${ }^{\circledR}$ & $61 \mathrm{cD}$ & $96 \mathrm{aA}$ & $84 \mathrm{bB}$ \\
\hline & Cruiser $^{\circledR}+$ Maxim xl $^{\mathbb{R}}$ & $64 \mathrm{cC}$ & $92 \mathrm{aB}$ & $76 \mathrm{bC}$ \\
\hline & Standak Top ${ }^{\circledR}$ & $69 \mathrm{cB}$ & $86 \mathrm{aC}$ & $77 \mathrm{bC}$ \\
\hline & Control & $71 \mathrm{cB}$ & $93 \mathrm{aB}$ & $90 \mathrm{bA}$ \\
\hline \multirow{6}{*}{$\begin{array}{c}\text { NS } 8693 \\
(\mathrm{VC}=1.96 \%)\end{array}$} & Cropstar $^{(B)}+$ Derosal Plus ${ }^{(B)}$ & $75 \mathrm{bD}$ & $93 \mathrm{aC}$ & $93 \mathrm{aB}$ \\
\hline & Cropstar $^{\circledR}+$ Maxim xl $^{\circledR}$ & $63 \mathrm{cE}$ & $98 \mathrm{aA}$ & $93 \mathrm{bB}$ \\
\hline & Cruiser $^{\circledR}+$ Derosal Plus ${ }^{\circledR}$ & $83 \mathrm{bB}$ & $100 \mathrm{aA}$ & $98 \mathrm{aA}$ \\
\hline & Cruiser $^{\circledR}+$ Maxim xl $^{\circledR}$ & $92 \mathrm{bA}$ & $95 \mathrm{aB}$ & $96 \mathrm{aA}$ \\
\hline & Standak Top ${ }^{\circledR}$ & $80 \mathrm{cC}$ & $98 \mathrm{aA}$ & $94 \mathrm{bB}$ \\
\hline & Control & $78 \mathrm{bC}$ & $91 \mathrm{aC}$ & $92 \mathrm{aB}$ \\
\hline \multirow{6}{*}{$\begin{array}{c}\text { NS } 7338 \text { IPRO } \\
(\mathrm{VC}=2.32 \%)\end{array}$} & Cropstar $^{(B)}+$ Derosal Plus $\left.{ }^{(}\right)$ & $79 \mathrm{cA}$ & $95 \mathrm{aA}$ & $83 \mathrm{bC}$ \\
\hline & Cropstar $^{\circledR}+$ Maxim xl $^{\circledR}$ & $65 \mathrm{cC}$ & $91 \mathrm{aB}$ & $82 \mathrm{bC}$ \\
\hline & Cruiser $^{\circledR}+$ Derosal Plus ${ }^{\circledR}$ & $63 \mathrm{cC}$ & $90 \mathrm{aB}$ & $87 \mathrm{bB}$ \\
\hline & Cruiser $^{\circledR}+$ Maxim xl $^{\circledR}$ & $55 \mathrm{cD}$ & $94 \mathrm{aA}$ & $84 \mathrm{bC}$ \\
\hline & Standak Top ${ }^{\circledR}$ & $72 \mathrm{cB}$ & $84 \mathrm{aC}$ & $77 \mathrm{bD}$ \\
\hline & Control & $70 \mathrm{cB}$ & $94 \mathrm{aA}$ & $90 \mathrm{bA}$ \\
\hline
\end{tabular}

The averages followed by the same low case letter in the lines and capital letter in the column do not differ between each other by the Scott-Knott test, at $5 \%$ probability.

to a reduction in the vigor. Based on the principle of cold test, we can see that when the seeds were sown and left for seven days at a temperature of $10{ }^{\circ} \mathrm{C}$ under $70 \%$ of the moisture retention capacity, there was the sudden entry of the seed treatment products causing an underwhelming performance for that specific cultivar, probably due to phytotoxicity.

The seeds of this same variety which were stored treated with Cropstar $^{\circledR}+$ Derosal Plus $^{\circledR}$, Cruiser $^{\circledR}+$ Maxim xl $^{\circledR}$,

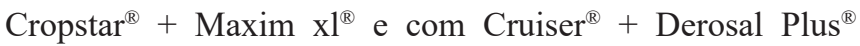
showed better performance regarding vigor. The percentage of normal seedlings emerged after the cold period remained when the seeds of the plant variety NS 7494 were treated after

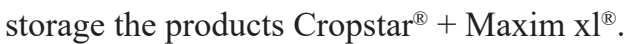

As well as cultivar NS 7494, the seeds of the 'NS 8693' that were treated with the Standak Top ${ }^{\circledR}$ product kept vigor after the cold test when the treatment was done pre test, however, the expression of quality was accentuated when the

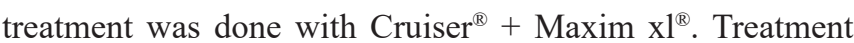
prior to storage has contributed to better expression of vigor regardless of the products used as treatment. The quality of the seeds that were stored and later treated remained for most products. Mixtures containing the insecticide Cruiser $^{\circledR}$ in its composition have contributed to better performance of these seeds vigor. Different from the result found by Tonim et al. (2014), researching the effect of treatment products on the quality of corn seed, a reduction in vigor were observed in storage for seeds treated with thiametoxan, i. a. of Cruiser ${ }^{\circledR}$, and with imidacloprido and tiocarbe, i. a. of Cropstar ${ }^{\circledR}$, and attributed the decrease of the vigor to the negative effects of active products to development of seedlings under adverse conditions after a short storage period.

The seeds of the cultivar NS 7338 IPRO, when treated preoperatively with products Cropstar ${ }^{\circledR}+$ Derosal Plus ${ }^{\circledR}$ obtained greater expression of the vigor regarding the control. With the exception of the Standak Top ${ }^{\circledR}$ product, which kept the quality of seed, the other products have contributed to the reduction of the vigor by the cold stress. For the seeds stored and treated after storage for two months, the worst treatment was with the Standak Top ${ }^{\circledR}$ product that has contributed to a lower expression of vigor of the seeds. This result is indicative that when in contact with the seeds for longer periods, the Top Standak ${ }^{\circledR}$ treatment product can have phytotoxic effects on seeds.

Likewise in the accelerated aging test, any one of the cultivars manifested high effect for treated seed and stored and low vigor to the treated seeds before the quality tests, which proves that the contact time of the fungicides with the seeds is important for the complete elimination of fungi since pathogens present in the soil or on the seeds reduce the soybean plants stand (Costamilan et al., 2012). Besides fungicide treatment not reducing physiological quality of seeds, it is extremely efficient in the control of pathogens, about $96 \%$ in the control of Aspergillus and Fusarium and $100 \%$ in control of Penicillium and Cercospora, such results 
can be confirmed in Table 5 with the health test results of this research (Pereira et al., 2007).

The percentage of seedling emergence from cultivar NS 7494 was greater when the treatment was performed after storage, except when the seeds were treated with the mixture

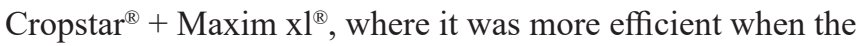
treatment was performed before the quality tests (Table 4).
The product of treatment Cruiser $^{\circledR}+$ Derosal Plus $^{\circledR}$ caused a better performance of the stored seeds treated with highest number of seedlings emerged, and kept the quality when the seeds were stored before treatment, opposed to the results found by Dan et al. (2013) who observed a reduction in emergence of seedlings along the storage with seeds treated with the insecticide Cruiser $^{\circledR}$.

Table 4. Emergence (\%) of seeds from three soybean cultivars treated with different products at different times of application.

\begin{tabular}{|c|c|c|c|c|}
\hline \multirow{2}{*}{ Cultivars } & \multicolumn{4}{|c|}{ Application Time } \\
\hline & Products & Treat & Treat + Stored & Stored + Treat \\
\hline \multirow{6}{*}{$\begin{array}{c}\text { NS } 7494 \\
(\mathrm{VC}=2.14 \%)\end{array}$} & 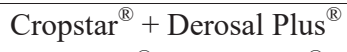 & $87 \mathrm{bC}$ & $92 \mathrm{aB}$ & $94 \mathrm{aB}$ \\
\hline & Cropstar $^{\circledR}+$ Maxim xl $^{\circledR}$ & $97 \mathrm{aA}$ & $79 \mathrm{cD}$ & $91 \mathrm{bC}$ \\
\hline & Cruiser $^{\mathbb{R}}+$ Derosal Plus $^{\mathbb{R}}$ & $91 \mathrm{cB}$ & $96 \mathrm{bA}$ & $100 \mathrm{aA}$ \\
\hline & Cruiser $^{\circledR}+$ Maxim xl $^{\circledR}$ & $85 \mathrm{bC}$ & $93 \mathrm{aB}$ & $93 \mathrm{aB}$ \\
\hline & Standak Top ${ }^{\circledR}$ & $90 \mathrm{aB}$ & $83 \mathrm{bC}$ & $89 \mathrm{aC}$ \\
\hline & Control & $94 \mathrm{bA}$ & $92 \mathrm{bB}$ & $98 \mathrm{aA}$ \\
\hline \multirow{6}{*}{$\begin{array}{c}\mathrm{NS} 8693 \\
(\mathrm{VC}=2.07 \%)\end{array}$} & Cropstar $^{(\mathbb{B}}+$ Derosal Plus ${ }^{\circledR}$ & $95 \mathrm{aA}$ & $89 \mathrm{bC}$ & $91 \mathrm{bB}$ \\
\hline & Cropstar $^{\circledR}+$ Maxim xl $^{\mathbb{B}}$ & $93 \mathrm{bB}$ & $95 \mathrm{aB}$ & $96 \mathrm{aA}$ \\
\hline & Cruiser $^{\circledR}+$ Derosal Plus $^{\circledR}$ & $96 \mathrm{bA}$ & $99 \mathrm{aA}$ & $94 \mathrm{cA}$ \\
\hline & Cruiser $^{\circledR}+$ Maxim xl $^{\circledR}$ & $92 \mathrm{bB}$ & $96 \mathrm{aB}$ & $94 \mathrm{aA}$ \\
\hline & Standak Top ${ }^{\circledR}$ & $95 \mathrm{aA}$ & $96 \mathrm{aB}$ & $85 \mathrm{bC}$ \\
\hline & Control & $97 \mathrm{aA}$ & $88 \mathrm{bC}$ & $97 \mathrm{aA}$ \\
\hline \multirow{6}{*}{$\begin{array}{c}\text { NS } 7338 \text { IPRO } \\
(\mathrm{VC}=2.21 \%)\end{array}$} & Cropstar $^{(\mathbb{R}}+$ Derosal Plus ${ }^{\circledR}$ & $85 \mathrm{bB}$ & $78 \mathrm{cE}$ & $92 \mathrm{aB}$ \\
\hline & Cropstar $^{\mathbb{R}}+$ Maxim xl $^{\mathbb{B}}$ & $88 \mathrm{cB}$ & $97 \mathrm{aA}$ & $92 \mathrm{bB}$ \\
\hline & Cruiser $^{\circledR}+$ Derosal Plus $^{\circledR}$ & $91 \mathrm{bA}$ & $97 \mathrm{aA}$ & $94 \mathrm{aA}$ \\
\hline & Cruiser $^{\circledR}+$ Maxim xl $^{\circledR}$ & $90 \mathrm{aA}$ & $87 \mathrm{bD}$ & $90 \mathrm{aB}$ \\
\hline & Standak Top ${ }^{\circledR}$ & $91 \mathrm{bA}$ & $90 \mathrm{bC}$ & $94 \mathrm{aA}$ \\
\hline & Control & $91 \mathrm{aA}$ & $94 \mathrm{aB}$ & $80 \mathrm{bC}$ \\
\hline
\end{tabular}

The averages followed by the same low case letter in the lines and capital letter in the column do not differ between each other by the Scott-Knott test, at $5 \%$ probability.

Either for cultivar NS 8693 or for cultivar NS 7338 IPRO, the best averages of seedlings were when seeds were treated

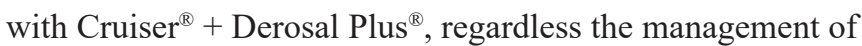
treatment used. The active ingredient thiametoxan Cruiser $^{\circledR}$ of insecticide is a bioatctivator that brings increments in germination, emergence and agronomic characteristics of seedlings through unknown mechanisms of morphological changes and metabolism (Dan et al., 2013). In addition to the advantages of this insecticide, for the protective effect of the fungicide Derosal Plus ${ }^{\circledR}$, which guarantees an ideal stand of seedlings in the field.

When the treatment was performed after storage of the seeds from cultivar NS 7338 IPRO, there has been greater seedling number, as well as on cultivar NS 7494, except for

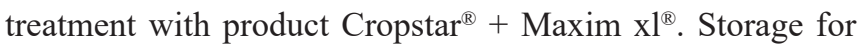
two months caused, naturally, a reduction of fungi that came from the field, the example of Fusarium in the percentage before the storage for the seeds to cultivar NS 7494 was 30\% and after storage was $0 \%$, and for cultivar NS 7338 IPRO was of $15 \%$ and reduced to $0 \%$, as shown in the results for the sanity of the seed (Table 5). Ludwig et al. (2011) also observed a reduction of Fusarium over soy seeds storage.

In assessing the sanitary quality of seeds, there was no significant effect, on all three cultivars, from the main fungi present in soy culture, Penicillium, Fusarium and Aspergillus (Table 2A).

In general, the products were efficient in the control of all cultivars seeds. It is observed that this efficiency is directly connected to the contact time of the products with the seeds (Table 5). The Maxim ${ }^{\circledR}$ fungicide and i. a. fungica action Standak Top ${ }^{\circledR}$ product require a contact period of two months with the seeds to act on reduction of fungi. On the other hand, the product Derosal Plus ${ }^{\circledR}$ was efficient in fungus control regardless of the moment in which the product application and grow.

However, despite the efficiency of treatment and storage in the control of fungi, reduction in germination and vigor of seeds more infested is observed, as has been shown in the results of physiological quality (Juhász et al., 2013). 
Table 5. Incidence (\%) of Penicillium sp. in seeds from three soybean cultivars treated with different products at different times of application.

\begin{tabular}{|c|c|c|c|c|c|c|c|c|c|c|}
\hline \multirow{4}{*}{ Cultivars } & \multirow{4}{*}{ Products } & \multicolumn{9}{|c|}{ Application Time } \\
\hline & & \multicolumn{3}{|c|}{ Penicillium } & \multicolumn{3}{|c|}{ Fusarium } & \multicolumn{3}{|c|}{ Aspergillus } \\
\hline & & & Treat & Stored & & Treat & Stored & & Treat & Stored \\
\hline & & Treat & $\stackrel{+}{+}$ & + & Treat & + & + & Treat & + & + \\
\hline \multirow{7}{*}{$\begin{array}{c}\text { NS } 7494 \\
(\mathrm{VC}=26.52 \%)\end{array}$} & Cropstar $^{\circledR}+$ Derosal Plus ${ }^{\circledR}$ & 0.4 & 0 ate & Ireat & $0 \mathrm{a}$ & $\frac{\text { Stored }}{0 a n}$ & Ireat & $0 \rightarrow$ & Stored & Treat \\
\hline & Cropstar $^{\mathbb{Q}}+$ Maxim xl $^{\mathbb{Q}}$ & da & a a & $0 \mathrm{aA}$ & oa & $0 \mathrm{aA}$ & $0 \mathrm{aA}$ & $0 \mathrm{AA}$ & 0 aA & $0 \mathrm{aA}$ \\
\hline & Cruiser $^{\circledR}+$ Derosal Plus $^{\circledR}$ & aD & aD & $2 \mathrm{aA}$ & se & da & $20 \mathrm{DB}$ & 0 a & 40B & $2 \mathrm{bA}$ \\
\hline & & $50 \mathrm{OD}$ & $\sigma$ aA & 0 aA & $2 \mathrm{aD}$ & 0 aA & 0 aA & 0 aA & 0 aA & 0 aA \\
\hline & Cruiser + Maxim XI & $13 \mathrm{bC}$ & $0 \mathrm{aA}$ & $13 \mathrm{bB}$ & $12 \mathrm{bC}$ & $0 \mathrm{aA}$ & $0 \mathrm{aA}$ & $9 \mathrm{bC}$ & $0 \mathrm{aA}$ & $10 \mathrm{bB}$ \\
\hline & Standak Top ${ }^{(B)}$ & $13 \mathrm{bC}$ & $0 \mathrm{aA}$ & $0 \mathrm{aA}$ & $4 \mathrm{bB}$ & $0 \mathrm{aA}$ & $2 \mathrm{bB}$ & $0 \mathrm{aA}$ & $0 \mathrm{aA}$ & $0 \mathrm{aA}$ \\
\hline & Control & $54 \mathrm{bD}$ & $6 \mathrm{aB}$ & $9 \mathrm{aB}$ & $30 \mathrm{cD}$ & $7 \mathrm{bB}$ & $0 \mathrm{aA}$ & $3 \mathrm{aB}$ & $7 \mathrm{bC}$ & $15 \mathrm{cC}$ \\
\hline \multirow{6}{*}{$\begin{array}{c}\text { NS } 8693 \\
(\mathrm{VC}=18.57 \%)\end{array}$} & Cropstar $^{\circledR}+$ Derosal Plus $^{\circledR}$ & $0 \mathrm{aA}$ & $0 \mathrm{aA}$ & $0 \mathrm{aA}$ & $2 \mathrm{aA}$ & $0 \mathrm{aA}$ & $2 \mathrm{aA}$ & $0 \mathrm{aA}$ & $0 \mathrm{aA}$ & $0 \mathrm{aA}$ \\
\hline & Cropstar $^{\circledR}+$ Maxim xl $^{\circledR}$ & $3 \mathrm{bB}$ & $0 \mathrm{aA}$ & $3 \mathrm{bB}$ & $15 \mathrm{cB}$ & $9 \mathrm{bB}$ & $2 \mathrm{aA}$ & $3 \mathrm{aA}$ & $4 \mathrm{aB}$ & $12 \mathrm{bB}$ \\
\hline & Cruiser $^{\circledR}+$ Derosal Plus ${ }^{\circledR}$ & $0 \mathrm{aA}$ & $0 \mathrm{aA}$ & $0 \mathrm{aA}$ & $3 \mathrm{bA}$ & $0 \mathrm{aA}$ & $0 \mathrm{aA}$ & $0 \mathrm{aA}$ & $0 \mathrm{aA}$ & $0 \mathrm{aA}$ \\
\hline & Cruiser $^{\circledR}+$ Maxim xl $^{\circledR}$ & $20 \mathrm{bC}$ & $0 \mathrm{aA}$ & $0 \mathrm{aA}$ & $58 \mathrm{cD}$ & $7 \mathrm{aB}$ & $12 \mathrm{bB}$ & $0 \mathrm{aA}$ & $0 \mathrm{aA}$ & $0 \mathrm{aA}$ \\
\hline & Standak Top ${ }^{\circledR}$ & $40 \mathrm{bD}$ & $0 \mathrm{aA}$ & $0 \mathrm{aA}$ & $26 \mathrm{bC}$ & $0 \mathrm{aA}$ & $0 \mathrm{aA}$ & $0 \mathrm{aA}$ & $0 \mathrm{aA}$ & $0 \mathrm{aA}$ \\
\hline & Control & $35 \mathrm{cD}$ & $8 \mathrm{aB}$ & $17 \mathrm{bC}$ & $85 \mathrm{bE}$ & $59 \mathrm{aC}$ & $66 \mathrm{aC}$ & $0 \mathrm{aA}$ & $5 \mathrm{bB}$ & $46 \mathrm{cC}$ \\
\hline \multirow{6}{*}{$\begin{array}{l}\text { NS } 7338 \text { IPRO } \\
(\mathrm{VC}=17.06 \%)\end{array}$} & Cropstar $^{\circledR}+$ Derosal Plus $^{\circledR}$ & $0 \mathrm{aA}$ & $0 \mathrm{aA}$ & $0 \mathrm{aA}$ & $1 \mathrm{aA}$ & $0 \mathrm{aA}$ & $0 \mathrm{aA}$ & $0 \mathrm{aA}$ & $0 \mathrm{aA}$ & $0 \mathrm{aA}$ \\
\hline & Cropstar $^{\circledR}+$ Maxim xl $^{\circledR}$ & $23 \mathrm{bB}$ & $15 \mathrm{aB}$ & $25 \mathrm{bB}$ & $13 \mathrm{cB}$ & $0 \mathrm{aA}$ & $6 \mathrm{bB}$ & $28 \mathrm{bB}$ & $10 \mathrm{aB}$ & $8 \mathrm{aB}$ \\
\hline & Cruiser $^{\circledR}+$ Derosal Plus ${ }^{\circledR}$ & $0 \mathrm{aA}$ & $0 \mathrm{aA}$ & $0 \mathrm{aA}$ & $3 \mathrm{bA}$ & $0 \mathrm{aA}$ & $5 \mathrm{bB}$ & $0 \mathrm{aA}$ & $0 \mathrm{aA}$ & $0 \mathrm{aA}$ \\
\hline & Cruiser $^{\circledR}+$ Maxim xl $^{\circledR}$ & $67 \mathrm{bD}$ & $0 \mathrm{aA}$ & $0 \mathrm{aA}$ & $11 \mathrm{bB}$ & $0 \mathrm{aA}$ & $0 \mathrm{aA}$ & $53 \mathrm{cC}$ & $0 \mathrm{aA}$ & $6 \mathrm{bB}$ \\
\hline & Standak Top ${ }^{\circledR}$ & $46 \mathrm{bC}$ & $0 \mathrm{aA}$ & $0 \mathrm{aA}$ & $11 \mathrm{bB}$ & $0 \mathrm{aA}$ & $0 \mathrm{aA}$ & $0 \mathrm{aA}$ & $0 \mathrm{aA}$ & $0 \mathrm{aA}$ \\
\hline & Control & $81 \mathrm{bD}$ & $40 \mathrm{aC}$ & $70 \mathrm{bC}$ & $15 \mathrm{bB}$ & $0 \mathrm{aA}$ & $0 \mathrm{aA}$ & $50 \mathrm{cC}$ & $16 \mathrm{aB}$ & $36 \mathrm{bC}$ \\
\hline
\end{tabular}

The averages followed by the same low case letter in the lines and capital letter in the column, of each fungi, do not differ between each other by the Scott-Knott test, at $5 \%$ probability. The original averages were presented but the data was compared with the transformed data (Transformation in $\left.(x+1)^{0.5}\right)$.

In general, the treatment before the seed quality tests was not detrimental to the quality, in ideal conditions, however, under conditions of stress, due to the concentration of the product, the performance of the seeds has been compromised, except with the use of mixtures containing the insecticide $\mathrm{Cruiser}^{\circledR}$. In addition, the contact time of the products with the seeds was not enough to reduce the incidence of fungi Fusarium, Aspergillus and Penicillium, except by the use of products based on Derosal Plus $^{\circledR}$, which contributed to reducing all fungi regardless if the seeds were not stored or treated.

With the use of products Cropstar ${ }^{\circledR}+$ Derosal Plus $^{\circledR}$, there were better expression of the physiological quality of seeds stored treated, whereas $\mathrm{Cropstar}^{\circledR}$ insecticide did not cause negative effects on the seeds and the fungicide Derosal Plus ${ }^{\circledR}$ was effective in reducing the three genera of fungi presented regardless of the time of application of the products. On the other hand, although the Standak Top ${ }^{\circledR}$ product has provided an initial start-up, established by germination test subsequently contributed to reducing the vigor of seeds stored treated as seedlings showed signs of phytotoxicity.

The quality of the seeds which have received treatment after the reduced storage with the use of products containing the insecticide Cropstar $^{\circledR}$ in its composition, contrary to the Cruiser $^{\circledR}$ insecticide which contributed to better performance of vigor of seeds under these conditions.

\section{Conclusions}

The chemical treatment with mixtures containing Cruiser $^{\circledR}$ (thiamethoxam) in its composition does not affect the physiological quality of soybean seeds when treated and assessed, and when application occurs after two months of storage.

Cropstar $^{\circledR}$ products (imidacloprido and tiocarbe) + Derosal Plus ${ }^{\circledR}$ (carbendazim and tiram) maintains the physiological quality of soybean seeds stored treated for a period of two months.

The product Standak Top ${ }^{\circledR}$ (fipronil, pyraclostrobin and thiophanate methyl) has negative effect on the quality of soybean seeds assessed and stored for two months.

Mixtures containing the insecticide Cropstar ${ }^{\circledR}$ in its composition reduces the physiological quality of soybean seeds when application occurs after two months of storage.

The fungicide Derosal Plus ${ }^{\circledR}$ improves the sanitary quality of soybean seeds regardless of time of treatment.

\section{References}

BRASIL. Ministério da Agricultura, Pecuária e Abastecimento. Regras para análise de sementes. Ministério da Agricultura, Pecuária e Abastecimento. Secretaria de Defesa Agropecuária. Brasília: MAPA/ACS, 2009. 395p. http:// www.agricultura.gov.br/arq_editor/file/2946_regras_analise_sementes.pdf 
BRZEZINSKI, C. C.; HENNING, A. A.; ABATI, J.; HENNING, F. A.; FRANÇA-NETO, J. B.; KRZYANOWSKI, F. C.; ZUCARELI, C. Seeds treatment times in the establishment and yield performance of soybean crops. Journal of Seed Science, v.37, n.2, p.147-153, 2015. http://www.scielo.br/ $\mathrm{pdf} / \mathrm{jss} / \mathrm{v} 37 \mathrm{n} 2 / 2317-1537-\mathrm{jss}-37-02-00147 . \mathrm{pdf}$

CASTRO, G. S.A.; BOGIANI, J.C.; SILVA, M. G.; GAZOLA, E.;ROSOLEM, C. A. Tratamento de sementes de soja com inseticidas e um bioestimulante. Pesquisa Agropecuária Brasileira, v.43, n.10, p.1311-1318, 2008. http:// www.scielo.br/scielo.php?pid=S0100-204X2008001000008\&script=sci arttext\&tlng=e

CONCEIÇÃO, G.M.; BARBIERI, A.P.P.; LÚCIO, A.D.; MARTIN, T.N.; MERTZ, L.M.; MATTIONI, N.M.; LORENTZ, L.H. Desempenho de plântulas e produtividade de soja submetida a diferentes tratamentos químicos nas sementes. Bioscience Journal, v.30, n.6, p.1711-1720, 2014. http://ainfo. cnptia.embrapa.br/digital/bitstream/item/113098/1/Desempenho-deplantulase-produtividade-de-soja-submetida-a-diferentes-tratamentosquimicos-nassementes.pdf

COSTAMILAN, L. M.; HENNING, A. A.; ALMEIDA, A. M. R.; GODOY, C. V.; SEIXAS, C. D. S.; DIAS, W. P. La Niña e os possíveis efeitos sobre a ocorrência de doenças de soja na safra 2010/2011. Londrina: Embrapa, 2012.

CUNHA, R.P.; CORREAA, M.F.; SCHUCH, L.O.B.; OLIVEIRA, R.C.; ABREU JÚNIOR, J.S.; SILVA, J.D.G.; ALMEIDA, T.L. Diferentes tratamentos de sementes sobre o desenvolvimento de plantas de soja. Ciência Rural, v.45, n.10, 2015. http://www.scielo.br/pdf/cr/2015nahead/0103-8478cr-cr20140742.pdf

DAN, L. G. M.; DAN, H. A.; BARROSO, A. L. L.; BRACCINI, A. L. Qualidade fisiológica de sementes de soja tratadas com inseticidas sob efeito do armazenamento, Revista Brasileira de Sementes v. 32, n.2, p. 131-139, 2010 .http://www.scielo.br/pdf/rbs/v32n2/v32n2a16.pdf

DAN，L.G.M.; BRACCINI, A.L.; BARROSO, A.L.L.; DAN, H.A.; PICCININ, G.G.; VORONIAK, J.M. Physiological potential of soybean seeds treated with thiamethoxam and submitted to storage. Agricultural Sciences, v.4, n.11, p.19-25, 2013. http://www.scirp.org/journal/PaperInformation. aspx?PaperID=40173

DANTAS, A. A. A.; CARVALHO, L. G.; FERREIRA, E. Classificação e tendências climáticas em Lavras, MG. Ciência e Agrotecnologia, v.31, n.6, p.1862-1866, 2007

FERREIRA, D.F. Sisvar: A computer statistical analysis system. Ciência e Agrotecnologia, v.35, n.6, p.1039-1042, 2011. http://www.scielo.br/pdf/ cagro/v35n6/a01v35n6.pdf

FOLLMANN, D. N.; SOUZA, V. Q.; NARDINO, M.; CARVALHO, I. R.; DEMARI, G. H. Diferentes associações para aditivos em pré-semeadura na cultura da soja e seus efeitos sobre a qualidade das sementes produzidas. Enciclopédia Biosfera, v.10, n.18. p.1284-1292, 2014. http://www.conhecer. org.br/enciclop/2014a/AGRARIAS/diferentes\%20associacoes.pdf

JUHÁSZ, A. C. P.; PÁDUA, G.P.; WRUCH, D.S.M.; FAVORETO, L.; RIBEIRO,N.R. Desafios fitossanitários para a produção de soja. Informe Agropecuário, v.34, n. 276, p. 66-75, 2013. https://www.alice.cnptia. embrapa.br/alice/bitstream/doc/978383/1/cpamtwruck010033642013.pdf
LUDWIG, M.P.; LUCCA FILHO, O.A.; BAUDET, L.; DUTRA, L.M.C.; AVELAR, S.A.G.; CRIZEL, R.L. Qualidade de sementes de soja armazenadas após recobrimento com aminoácido, polímero, fungicida e inseticida. Revista Brasileira de Sementes, v.33, n.3, p.395-406, 2011. http://www.scielo.br/ scielo.php?pid=S0101-31222011000300002\&script=sci_arttext

MAPA- Ministério da Agricultura Pecuária e Abastecimento. http:॥www. agricultura.gov.br. Accessed on: Jan, 30 3016.

MARCOS-FILHO, J. Teste de envelhecimento acelerado. In: KRZYZANOWSKI, F.C.; VIEIRA, R.D.; FRANÇA-NETO, J.B. (Ed.) Vigor de sementes: conceitos e testes. Londrina: ABRATES, 1999. p.3.1-3.21.

NEERGAARD, P. Seed Pathology. London: Macmillan Press, 1979. 839p.

PEREIRA, C. E.; OLIVEIRA, J. A.; EVANGELISTA, J. R.E.; BOTELHO, F. J. E.; OLIVEIRA, G. E.; TRENTINI, P. Desempenho de sementes de soja tratadas com fungicidas e peliculizadas durante o armazenamento. Ciência e Agrotecnologia, v.31, n.3, p.656-665, 2007. http://www.scielo.br/pdf/cagro/ v31n3/a09v31n3.pdf

SALES, J. F.; PINTO, J.E.B.P.; OLIVEIRA, J.A.; BOTREL, P.P.; SILVA, F.G.; CORREAA, R.M. The germination of bush mint (Hyptis marrubioides EPL) seeds as a function of haverst stage, light, temperature and duration of storage. Acta Scientiarum Agronomy, v.33, n. 4, p.709-713, 2011. http:/ www.scielo.br/pdf/asagr/v33n4/22.pdf

SOUZA, V.Q.S.; FOLLMANM, D.N.; NARDINO, M.; BARETTA, D.; CARVALHO, I.R.; CARON, B.O.; SCHMIDT, D.; DEMARI, G.H. Produção de sementes de soja e vigor das sementes produzidas com diferentes tratamentos de sementes. Global Science Technology, v.8, n.1, p.157-166, 2015. http://rv.ifgoiano.edu.br/periodicos/index.php/gst/article/ view/703/454

TONIM, R.F.B.; LUCCA FILHO, O.A.; LABBE, L.M.B.; ROSSETO, M Potencial fisiológico de sementes de milho híbrido tratadas com inseticidas e armazenadas em duas condições ambiente. Scientia Agropecuária, v.5, n.1, p. 7-16, 2014. http://www.scielo.org.pe/pdf/agro/v5n1/a01v5n1.pdf

ZAMBOM, S. Aspectos importantes do tratamento de sementes. Anuário Abrasem, Brasília, p. 24-25, 2013. http://www.abrasem. com.br/anuario-2013/

ZILLI, J. E.; CAMPO, R. J.; HUNGRIA, M. Eficácia da inoculação de Bradyrhizobium em pré-semeadura da soja. Pesquisa Agropecuária Brasileira, v.45, n.3, p.335-338, 2010. http://www.scielo.br/pdf/pab/v45n3/ v45n3a15.pdf

ZORATO, M.; HENNING, A. Influência de tratamentos fungicidas antecipados, aplicados em diferentes épocas de armazenamento, sobre a qualidade de sementes de soja. Revista Brasileira de Sementes, v.23, n.2, p.236-244, 2001. http://www.abrates.org.br/revista/artigos/2001/v23n2/ artigo33.pdf 